2-9-2015

\title{
Globalization and the University: A Relationship Worth Studying?
}

Alan Ruby

University of Pennsylvania, alanruby@gse.upenn.edu

Follow this and additional works at: https://repository.upenn.edu/gse_pubs

Part of the Higher Education Commons, and the International and Comparative Education Commons

\section{Recommended Citation (OVERRIDE)}

Ruby, A. (2015). Globalization and the University: A Relationship Worth Studying?. In B. Spooner (Ed.), Globalization: The Crucial Phase (pp. 343-358). Philadelphia, Pennsylvania: University of Pennsylvania Press. 


\section{Globalization and the University: A Relationship Worth Studying?}

Keywords

globalization, higher education

Disciplines

Education | Higher Education | International and Comparative Education 


\title{
Globalization and the University: A Relationship Worth Studying?
}

\author{
Alan RuBY
}

\section{INTRODUCTION}

$\mathrm{T}$ he purpose of this chapter is to show that globalization affects universities and that there is a lot about the phenomena of globalization and its interaction with institutions of higher learning that merits study, not least of which is the way those institutions can contribute to and shape globalization. I begin with a definition of globalization and how it affects some of the constituent parts and populations of institutions of higher education. Then I examine those in more detail before going on to suggest three ways in which scholars and researchers might add to our knowledge about globalization. I will give one example of how systematic inquiry would increase our understanding of the market for international higher education students and then suggest some other approaches of inquiry and finally offer some suggestions about future research in this area.

\section{A WORKING DEFINITION BASED ON THE MOVEMENT OF FORMS OF CAPITAL}

Despite the avalanche of literature about globalization in the last twenty years there is still some debate about how it is defined as scholars from dif- 
ferent disciplines have written about the current wave of closer technological, economic and demographic integration between nations and communities. Others can debate the various attempts at definitions. Here the focus is on one common element: the ease or freedom of movement between economies of three forms of capital, financial capital, intellectual capital, and human capital. As "globalization" occurs through technological advances, changes in the laws and treaties governing cross- national trade, and the recognition of qualifications, national boundaries become more permeable to the movement of money, ideas, and people. As a consequence all three forms of capital move more quickly and easily between nations and markets. Universities as institutions involved in the creation of knowledge and the development of human capacity contribute to the stock of capital that can and does move and facilitate that movement through actions, policies and processes of scholarship and teaching. Of course things other than capital move more easily because of globalization: goods, services other than education, and disease are ready examples. These movements also attract the interests of scholars and educators. They offer opportunities for study, present new cross-national problems for researchers, and influence curricula for health professionals and so on.

\section{GLOBALIZATION AND EDUCATION THROUGH THE LENS OF TRADE IN SERVICES}

Education is included in the agreements between nations brokered under the GATS framework (General Agreement on Trade in Services). This allows governments to recognize education as a trade "good" and to enter into arrangements with other nations about market access. Over 50 nations have treaties or agreements that cover aspects of education and many of them cover higher education. These legal provisions make it easier for institutions to sell educational services to students from other sovereign nations.

The trade in educational services can be classified into four modes of delivery (cf. Suave 2002). The first is cross-border supply, where an institution domiciled in one nation provides education to a student in another. The most obvious example of this is distance or virtual education where the instructor and the student are in different locations or time zones. Delivery and consumption do not have to be simultaneous. There are no 
real constraints on the scale of provision, and the legal framework governing the arrangement is usually that of the provider's nation. This sector is relatively small but growing quickly. The second mode is "consumption abroad" where the student moves to the location of the provider. International students are a ready example and the numbers have grown rapidly in the last 20 years and continue to grow. There are now more than 4.1 million people studying at the post-secondary level outside their country of citizenship (OECD 2012:24) and while growth is difficult to predict, as demand is shaped by aspiration, economic realities, and the availability of high quality domestic opportunities, it is likely to continue to grow. The third mode is usually referred to as "a commercial presence" where the provider has established a revenue attracting entity in another nation. Usually this would be a branch campus offering a small range of courses or degrees rather than a full academic program. There are examples like Nottingham in Ningbo and New York University in the Arab Emirates where the "branch" is a complete institution or in New York University jargon a "portal." The final mode of trade in educational services is described as "the movement of natural persons." Essentially this is mobile faculty: people from the home campus physically present and teaching in another sovereign nation. There is no reliable data on this partly because definitions are not set and because people move using different visa classes for different periods of time. Some argue that faculty mobility is constrained by the customs and mores of a tenure path academic culture that offers no incentive for international service. Others observe that tenure is not open to or indeed the aspiration of all and that other constraints on mobility like family and personal responsibility are more telling. All four forms of delivery of educational services are facilitated by and contribute to globalization.

\section{STUDYING THE INTERACTION BETWEEN GLOBALIZATION AND THE UNIVERSITY}

A simple beginning would be to look systematically at how higher education institutions contribute to "globalization" and how they are affected by it as illuminated by the actions of universities as "providers" of human and intellectual capital and at the behavior of the consumers of university teaching-students. Then we can look at how the products of universities — credentials and the people who hold them—are affected by globaliza- 
tion and how different modes of university teaching or knowledge transfer contributes to "globalization."

One way in which higher education institutions have responded to globalization is to become more "international." Some have sought to do that by opening up courses and content to students in other locations through various forms of distance education or by making course materials freely available. MIT's Open Course Ware is a leading example. However, the big distance education universities, located in Turkey, Indonesia and China are still focused on domestic markets and extending access to citizens rather than meeting global demand.The rapid growth of massive on line courses (MOOCs) beginning in mid-2012 may broaden access to higher education, but data from the first year of six MOOCs at Edinburgh University shows that most users were from developed nations with strong domestic higher education systems (Edinburgh University 2013). This may change as MOOCs evolve and the take up from currently underserved populations increases but more evidence is needed to support claims that MOOCs will be an effective tool to increase access to higher education (Perna and Ruby 2013).

Most universities have endeavored to become more international by changing the composition of the undergraduate population. Institutions have become less homogenous in terms of country of origin, nationality, and cultural identity as they have opened up to the "cross border supply" of students. Table 14.1 shows the ten U.S. Universities with the largest populations of international students, ranked in numerical order. The order would change if the ranking was based on the proportion of international students in the total student population. At Columbia University for example almost 1 in 4 of the total student population is an international student and in Fall 2012 they came from 139 countries (Columbia University 2012).

A more diverse student population presents challenges to university leaders. It could be simply the influence on student life where suddenly the range of interests, activities and religions has expanded. Should cricket join lacrosse as an intervarsity sport? Do we offer space for worship for Russian Orthodox and Episcopalian congregations and does the university finance student clubs for the multiplicity of ethnic groups within the Vietnamese community? All become time consuming questions for administrators.

Teaching becomes more complex and more demanding as the diversity of the student population increases. Over the past 40 years as higher education became a "mass" institution-to use Martin Trow's taxonomy- 
Table 14.1 U.S. Institutions with largest numbers of International Students 2011/2012 (IIE Open Doors 2012)

\begin{tabular}{|l|l|l|}
\hline Rank & Institution & $\begin{array}{l}\text { Number of } \\
\text { Students }\end{array}$ \\
\hline 1 & University of Southern California & 9269 \\
\hline 2 & University of Illinois- UC & 8997 \\
\hline 3 & New York University & 8660 \\
\hline 4 & Purdue University- Main Campus & 8563 \\
\hline 5 & Columbia University & 8024 \\
\hline 6 & UCLA & 6703 \\
\hline 7 & North Eastern & 6486 \\
\hline 8 & University of Michigan & 6382 \\
\hline 9 & Michigan State University & 6209 \\
\hline 10 & Ohio State University- Main Campus & 6142 \\
\hline
\end{tabular}

teachers were confronted with the challenges of dealing with a student population that came with very different forms of cultural capital and very different vocational aspirations. They were no longer dealing just with the children of the elite and they had to adjust programs and teaching methods accordingly. Yet, they were, by and large, dealing with a majority culture. Since the mid-1980s the challenges of mass higher education have deepened as domestic student participation levels have increased but especially as the international student body has increased in size. International students bring very different histories and experiences of academic life and often have different expectations about classroom practice and behavior. Student motivations are sometimes more intensely focused on vocational preparation and achievement. These differences can be as simple as unquestioning and passive participation in graduate seminars that are being conducted in a Socratic mode to as complicated as ignorance of academic integrity codes. While these are important institutional matters, the focus here is more on the broader policy issues involved in globalization and its interrelationship with universities.

One of those issues is how a university responds to its more global environment when it wishes to do more than simply enroll a number of international students or to diversify where those students come from. Some institutions have pursued the third mode of trade in educational services 
by creating branches or franchises in other economies or nations. By some counts there are over 200 degree awarding branch campuses (Lawton and Katsomitros 2012). American institutions operate in more than 40 economies that vary in size from Bermuda to China and in political system from parliamentary democracy (Australia) to state Communism (Vietnam). Institutions in many other nations, like Britain, are also setting up branch campuses. Some of the branches and programs aim to increase the revenue and reputation of the home college, while others seek to maximize the institution's international character. Still others are driven by institutional altruism and a desire to help less-fortunate communities.

The for-profit sector has also been active abroad. The Apollo Group has been buying degree-awarding entities in Britain and Chile; Laureate Education is expanding in Central and Latin America, and DeVry operates programs in the Caribbean and Brazil. They are but three of more than 70 well-capitalized investors looking at the global market.

Branch campuses are not new. The religious orders opened branches in India for example in the 1800s and there was a wave of U.S. branch campuses in Japan starting in the 1970s when its economy was booming and the U.S. was stagnant. Few of the branches in Japan were successful and only Temple University's campus in Japan still operates, and it finally "broke even" financially in 2009.

Many of those that failed simply overestimated demand or did not foresee economic or cultural barriers to success. In 2007, Australia's University of New South Wales had to abandon its Singapore outpost during the first semester of operation. The enrollments just weren't there, with less than half the projected 300 students attending. The local market was saturated, and one-third of Singapore's college students were already attending institutions abroad. The fiscal incentive-a wage premium for a Western education - was eroding, as the supply of graduates increased and growth in the economy slowed. The social incentive of a "Western lifestyle" that had attracted 400 or more students to the home campus in Sydney was not transferable to the planned Changi campus.

Some branch campuses offered too many programs, some chose illogical locations and some selected partners looking for more immediate profits than a university could provide. Carnegie Mellon University, on entering Japan, sought to apply lessons from the efforts of others. Setting modest goals, it is offering programs for niche markets in which demand is strong 
and there is no competition, like the master's program in entertainment technology that it began in Osaka in 2008.

Some institutions have created partnerships rather than branches. This can range from shared programs where courses are designed by faculty at one institution and delivered by them and local instructors at another institution to arrangements where short courses at one school are recognized by another as counting towards a degree. There are seemingly endless variations involving distance education, faculty and student exchanges, certificates of participation, transfer requirements, and course credits. Some are ephemeral-flowering and fading with the interests of particular faculty or students and others endure. An example of the later is Oberlin College's fascinating history in China which began with the Oberlin Mission in the 1880 's which created an educational institution in Shansi province. The massacre of Christian missionaries during the Boxer uprising closed the school and it was revived a few years later and endured to the late 1940's and was revived again after the Korean war. It continues as an educational exchange and support program-a 130 years since its inception.

While these partnerships have been around for a long time, while the sums of money involved are significant investments, and while the numbers of campuses and students involved has increased dramatically, there is little systematic analysis of these developments. The Observatory of Borderless Higher Education's surveys are a good beginning but there is no detailed study of the business success and failure of branch campuses and only the beginnings of a systematic study of the due diligence process that should precede the creation of a campus in another nation. (See Box 1 below which first appeared in The Chronicle of Higher Education [Ruby 2010].)

\section{DIVERSIFYING THE SERVICE}

Rather than look externally-new locations and new markets-some universities have sought to increase the international or global character of the educational experience they offer. They seek to diversify the course offerings, broaden or change the languages and area studies offered, open service opportunities in other countries and introduce courses and degree programs called "global studies" (see Appalachian State University for one of many examples). In U.S. institutions the most prominent change in the last 15 years has been the growth of study abroad programs. While still 


\section{Box 1: Questions to Ask Before Setting Up A Branch Campus}

- Does a branch campus align with the institution's mission and values?

- Are you offering a broad liberal education or a low-cost, high-demand program like business and information technology?

- Who is putting up the capital? Is there an escrow payment to protect students from institutional default?

- Who owns the land? Is there anything already on the land?

- Whose "brand" is at risk? If the branch fails, how much impact would that have on the home institution's or host nation's name or the perceived reliability of the latter's education system?

- How will revenues be allocated, both among the parties and across operations?

- How much demand is there? Who else might be trying to serve the market?

- Will the tuition be set solely in terms of the local market, or will it reflect the global value of the service-the education received-and any subsequent globally recognized credential?

- Can any profits be repatriated to the home institution or foreign investors?

- Will there be differential tax treatment or taxes and levies on international commercial exchanges?

- What will be the language of instruction, and who will teach? Will certain courses be mandatory, and who will teach them?

- Are domestic institutions subsidized directly, or indirectly through scholarships? Can you get either form of subsidy? If so, at what cost in terms of regulatory oversight or admissions requirements?

- Can you build on existing academic or study-abroad partnerships? On an alumni base?

- How do you plan to attract and retain top faculty members? (Offering salary premiums and housing incentives has usually not attracted significant numbers of home-campus professors to serve on branch campuses. And there may be restrictions on the number of visas and length of stay. Finding well-credentialed local faculty members can be difficult as well.)

- How long a commitment can you make? Sometimes that question is best asked as, "How much money can you afford to lose?" 
less than $2 \%$ of four year degree students study abroad each year the total number of students studying abroad for academic credit increased to over 270,000 in 2010/2011 (International Institute for Education 2012). There has been steady growth of study abroad student numbers for the last 10 years. This growth has been partly matched by a diversification of destinations and a broadening of the disciplines that these students come from. Some schools have designed thoughtful programs that allow students from engineering and nursing to pursue study abroad opportunities. There is a small but growing body of research on the motivation to study abroad, on what constitutes good practice, and on the academic and vocational benefits of study abroad (see Vande Berg, Paige and Hemming Lou [2012] for a survey).

\section{AN EXAMPLE OF A PRESSING RESEARCH NEED: THE IN- TERNATIONAL STUDENT MARKET}

The area most in need of systematic research is the international student market. How big is it? What is its economic value? Can we forecast its scale accurately or reliably? What factors are shaping demand and what factors may slow growth?

Why are these questions worth considering? First it is always desirable to test conventional wisdom. For example "It is good for the economy" has been the dominant public policy maxim to justify government's supporting inflows of international students since the 1980s. There are other reasons. At the national level, international students are important strategically and diplomatically. Their presence has various benefits-fostering global engagement and cross-cultural understanding, promoting freedom and democracy, and easing tensions between nations. International students have become elements in the "soft power" approach to international relations (Atkinson 2010). Institutionally, students from other cultures and economies diversified the student body and symbolized the international mission of colleges and universities. They also brought fee revenue, an important factor, as state support was reduced by economic circumstances and shifts in ideology.

For national policy-makers looking for economic growth in a knowledge economy, selling services to international students was an opportunity to diversify the industrial base of a nation. Education could become an 
'export' industry bringing foreign capital to domestic institutions. Australia, New Zealand, Canada, and the United Kingdom were the most aggressive in pursuing revenue. By 2009, one in five university students in Australian universities was an international student and most were "full fee" paying, making them a vital part of an institution's operating budget. And in 2011 a few provincial universities, like the University of Ballarat, seventy miles inland from Melbourne, had populations were two in five students were international students.

At the national level, international students were seen to create jobs, pay taxes, consume locally produced goods and services, and create other indirect benefits that would multiply the value of each student's expenditure on themselves and their dependents. It was a "good thing" for the universities and the economy. In some countries such as the U.K. and Australia these benefits justified state expenditures on marketing and promotion to increase demand and hence revenue. Growth in revenue generating, cross-border students was rapid from 800,000 in 1999 to around four million in 2012. This is separate from the numbers of students involved in the other three "modes" of international education, where academics move, where the service crosses national boundaries and when programs cross borders. Political and institutional leaders promoted and defended the international student market with claims about the "value" of the industry. The economic value was often referred to in terms of "export" income and the education and training industry was favorably compared with other big export earners.

Popular comparisons in Australia were to claim that education was second to iron ore and coal as an export earner and was worth more than tourism(Australian Education International 2011). In British Columbia, foreign students are compared with fishing and trapping and the Vancouver film industry as contributors to the provincial economy. The most recent analysis for Canada compares international students' spending in Canada with the value of aluminum exports (Kunin and Associates 2012:iii).

Positioning higher education as an export industry was rational but it begs the question: just how valuable is this industry? As the numbers of international students grew so did the estimates of the value of the market for particular nations. Recent public estimates (in U.S. dollars at current exchange rates) range from $\$ 22.7$ billion for the U.S., $\$ 16$ billion for Australia, $\$ 21.1$ billion for the U.K., $\$ 8$ billion for Canada (Kunin and Associates 2012:9) to $\$ 1.5$ billion or more for New Zealand. The estimates appear pe- 
riodically and were largely unchallenged until late 2009 when Birrell (2009), an Australian demographer with a long-time interest in immigration and international students, claimed that the estimates for Australia numbers were wrong and wrong by as much as $50 \%$.

The sources of error were allegedly buried in the statistical methods used, out-dated expenditure data, and incorrect assumptions about the spending power of the international student population. Birrell challenged the emphasis on export earnings, arguing the total revenue needed to be discounted for local wages earned by international students. The industry leaders were quick to respond, pointing out mistakes in the analysis and flawed logic including omitting some of the non-educational expenditures of students and overlooking the downstream economic benefits of students' work earnings (Withers 2009). Five years ago this little disagreement would probably have passed unnoticed or been dismissed as a nerdish spat. Today, however, the stakes are assumed to be substantial, because the numbers for the national markets have continued to grow and because some institutions depend on the revenue from international students for financial stability.

Universities in the U.K., Australia and New Zealand draw more than $10 \%$ of their revenue from international students. In some markets and some sectors within individual national markets—such as English language training and vocational skills courses-private for-profit providers have opened colleges and programs almost solely for foreign students. They need good, timely, and reliable market intelligence to do business planning and attract investors. At a more macro level economic planners and strategists are trying to monitor and predict capital flows between economies and, while the numbers are below an airline or bank bail out, they are significant in smaller economies.

So why not simply add the national figures? Well, the popular estimates fail the 'eyeball' test. If the U.S. has 750,000 international students worth $\$ 21.8$ billion, how can Australia with around 470,000 students get an economic impact of $\$ 16$ billion? Australia is a slightly lower cost destination and it does sell education at lower price than the U.S. but the per capita differences seem too wide ( $\$ 28.5$ thousand per student in the U.S. versus $\$ 34.2$ thousand per student in Australia). It just does not "add up" because the estimates are derived using different methods and by different types of actors, ranging from national statistical agencies to a private consulting firm to a team led by a very dedicated international admissions director officer 
on behalf of a non-profit international education and training organization.

Unfortunately, there is no agreed global standard for estimating the economic worth of an individual international student to industrialized economies. The methods of estimation range from the addition of average tuition and direct living costs to the use of course specific costs and different assumptions about family size for graduate students to more sophisticated econometric modeling that takes into account the indirect impact through job creation in other sectors and tax revenue. Even if there was agreement about the methodology, there is also variance in the way the multiplierthe number of 'international students'-is calculated in different nations. So, there are plenty of sources of error.

Domestic policy makers and institutions have no real motivation to make these estimates more reliable. Estimates of national market size and value do not need to be internationally comparable for annual business planning and sources of error at least remain constant and do not confound cross year monitoring and trend analysis. Even these shortcomings can be problematic for domestic providers as the U.K. found when it underestimated its international student population by $20 \%$ because of how it treated resident foreign nationals.

Concentrating on the domestic market numbers overlooks the fact that the international student industry operates in a global market with institutions in different nations competing for volume, market share, and revenue against each other. Between 2012 and 2013, three of the biggest providers of education services, U.K., Canada, and Australia released international student market forecasts for the next ten or more years underscoring the idea that the market is "global" and that students seeking education through English language programs have a range of choices. It also underscored the existence of competition between nations for the best students. (See Ruby [2013] for a discussion of all three forecasts.)

The nations providing students and seeing an outflow of domestic capital are also interested in the current and future size of at least their portion of the industry - both in terms of currency flows and controls and in terms of skill formation and human capital creation. The sending and the receiving nations need global market intelligence to value demand and supply of educational services to guide policy-makers and providers. The individual purchasers also need better information about costs and supply. This will help them make choices about country of destination, of institution and 
of program of study. It will also help them make assessments of country and institutional supply and selectivity, relative costs and potential return on investment. Returns are not solely a function of price of tuition but are also influenced by living costs and by income on graduation for holders of particular qualifications. Some markets have seen a decline in demand and compensation for students with international qualifications.

Transparency and reliability of information are very important when the provider and the purchaser are geographically separated at the time of choice of product and payment. For the five big Anglophone providing nations and in Japan, around $90 \%$ of international students are 'self -financing' and are risking their own resources by making choices with little information. They often are forced to rely on 'commission agents,' whose incentives are to maximize enrolments in institutions that pay the agent the most, or on anecdote, rumor or commercial publications such as U.S. News and World Report rankings. None of these are interested in cross-national comparisons or global comparisons and none are interested in protecting the consumer. In summary, national policy-makers, institutional providers and investors, and potential students would all benefit from more reliable and more readily available data about the size and value of the international student market. It all sounds nice and logical, but is it really worth the effort?

If the numbers involved were still less than one million it might be debatable. If we take the 'best' estimate of four million students as the current year multiplier and assume unfairly and simplistically that the total unit value is $\$ 35,000$ (the sum of average U.S. tuition for an international student of $\$ 16,000$ plus U.S. average living expenses of $\$ 18,000$ and $\$ 1,000$ in other costs such as immigration and processing fees), the global market has a potential value of $\$ 140$ billion. Arbitrarily discounting the unit value by 15,000 for lower cost destinations and less costly programs produces an estimated global market value of $\$ 90+$ billion. This is still a number that commands attention. Of course, the global demand for post-secondary school education is expected to continue to grow and the number of international students could increase to five million-a conservative prediction-by 2025 . Using the lower unit value of $\$ 20,000$ the potential global value is $\$ 100$ billion in today's monetary values (Ruby 2009).

Both the current value and possible future value justify serious work on monitoring the global market and getting a better grip on both the numbers and the economic benefits involved. There is a case for some sustained 
research in this area. The challenges are significant: there is no agreement among national agencies or international interest groups like the OECD and the Institute for International Education on the number of international students now or the likely growth or decline in the numbers for the next five or ten years. There is no agreed formula for estimating the economic value of international students and there is not even agreement about the definition of who is an international student. Thus, there is real work to be done to determine if this is $\$ 100$ billion dollar industry.

\section{OTHER LENS OF ANALYSIS}

Not everyone finds the human capital or economic approach to international students and globalization acceptable or comfortable. It is too materialist or too instrumental. It overlooks the importance of the individual and social benefit that comes from a world-class education. It tends to over value the vocational preparation programs in universities at the expense of a broad liberal arts education that "creates knowledge" and opens the mind of students - to paraphrase the mission of the Harvard undergraduate college.

There is room for such criticisms and there are other ways of looking at international student flows between nations and at other aspects of globalization and its interrelationship with universities. For example, there is a rich literature on the ethical and moral dimensions of "brain drain" and "brain circulation" especially in the medical occupations (Chen et al. 2004; Clemens 2009). Others look at the legal dimensions and the recognition of qualifications across borders and the accreditation of institutions that market services in other nations through commission agents. These and others are legitimate perspectives on a complex and under studied phenomenon.

There is also scope for work on identifying predictors of demand for cross-border education. Is it largely driven by the growth of the middle class in nations with limited supply of high quality post-secondary school education? Is it simply a mismatch between demographic change- a rapidly growing youth population that outstrips the available or affordable infrastructure? Or is demand linked to economic diversification which increases the demand for skill and hence vocationally oriented further education? How we do factor in increased individual and family aspirations and social changes in attitudes towards the education of girls? There are many profitable avenues for work as we try to understand the interconnection of universities and globalization. 


\section{CONCLUSION}

In summary, there is a clear case that globalization has an effect on universities and that the actions of universities contributes to increased globalization by promoting movement of people and ideas across national borders. The movement of people for short or longer periods of time is increasing but the numbers involved and the economic value of this movement is poorly quantified and merits continued study.

\section{REFERENCES}

Atkinson, C. 2010. Does Soft Power matter? A comparative analysis of student exchange programs 1980-2006). Foreign Policy Analysis 6:1-22.

Australian Education International. 2011. Export Income to Australia from Education Services in 2010-11, Research Snapshot, November 2011. www.aei.gov.au/research

Birrell, B. 2009. Exports of Educational Services Attributable to the Overseas Students Industry in Australia. University World News, August 2009.

Chen, L., et al. 2004. Human Resources for Health: Overcoming the crisis. Lancet 364:1984-1990.

Clemens, M. 2009. Skill Flow: A fundamental Reconsideration of Skilled-Worker Mobility and development. Center for Global Development, Working paper 180, August 2009.

Columbia University. 2012. International Students at Columbia University, Fall 2012. www.columbia .edu/cu/isso/fallreport/Fall_Report_2012.pdf

Edinburgh University. 2013.MOOCs@ Edinburgh 2013-Report \#1.10 May 2013.www. era.lib.ed.ac.uk

International Institute for Education. 2012. Open Doors Report on International Education Exchange, 2009. Available through the IIE website, http:/ / www.iie.org.

Kunin and Associates. 2012. Economic Impact of International Education in Canadaan Update. Final Report. May 2012. http:/ /www.international.gc.ca/education/ assets/pdfs/economic_impact_en.pdf.

Lawton, W., and A. Kasomitros. 2012. International Branch Campuses: Data and developments. The Observatory on Borderless Higher 2102. www.obhe.ac.uk .

OECD. 2012. Education at a Glance 2012:Highlights. Paris: OECD. www.oecd.org/edu/ highlights.pdf.

Perna, L., and A. Ruby. 2013. The Silver Bullet of Education? ScienceGuide 21 May 2013. www.scienceguide.nl/201305. 
Ruby, A. 2009. International Students: A \$100 Billion dollar industry? University World News, September 27, 2009.

- 2010. Thinking About a Branch Campus? Think Twice. Chronicle of Higher Education March 21, 2010.

2013. Where Will International Students Go? ScienceGuide 10 June 2013. www.scienceguide.nl/201306.

Suave, P. 2002. Trade, Education and GATS. What's in, What's out and What's all the fuss about? Paris: OECD.

Vande Berg, M., R.M. Paige, and K. Hemming Lou, eds. 2012. Student Learning Abroad: What Our Students Are learning, What They're Not, and What We can Do About It. Sterling: Stylus Publishing.

Withers, G. 2009. Sector’s $\$ 15$ Billion—plus export figures really stack up. The Australian August 2009. 